\title{
PERAN COREPORATE SOCIAL RESPONSIBILITY TERHADAP HUBUNGAN ANTARA STRUKTUR KEPEMILIKAN DAN NILAI PERUSAHAAN
}

\author{
Muhammad Muttaqin ${ }^{1}$, Muhidin ${ }^{2}$ \\ 1,2Universitas Muhammadiyah Surakarta, taqinsarungan@gmail.com; \\ muhidinsarungan@gmail.com
}

\begin{abstract}
ABSTRAK
Tujuan dari penelitian ini adalah untuk menguji pengaruh kepemilikan institusional, kepemilikan manajerial dan kepemilikan asing terhadap nilai perusahaan dengan pengungkapan CSR sebagai variabel intervening. Populasi dalam penelitian ini adalah perusahaan sektor tekstil dan garmen yang terdaftar di Bursa Efek Indonesia pada tahun 2015 sampai 2019. Teknik pengambilan sampel dengan menggunakan metode purposive sampling, sehingga diperoleh jumlah sampel sebanyak 50 sampel . Hasil penelitian menunjukkan bahwa secara simultan struktur kepemilikan memiliki pengaruh terhadap pengungkapan CSR, hasil penelitian lain menunjukkan secara partial struktur kepemilikan tidak memiliki pengaruh terhadap pengungkapan CSR. Hasil penelitian juga menunjukkan bahwa struktur kepemilikan dan pengungkapan CSR secara simultan memiliki pengaruh terhadap nilai perusahaan. Kemudian yang secara parsial kepemilikan institusional, dan kepemilikan asing memiliki pengaruh negatif terhadap nilai perusahaan. Sementara kepemilikan manajerial dan pengungkapan CSR tidak berpengaruh terhadap nilai perusahaan, dan pengungkapan CSR bukan sebagai mediating dari stuktur kepemilikan terhadap nilai perusahaan. Hasil penelitian ini menunjukkan bahwa struktur kepemilikan belum berjalan sesuai tujuan perusahaan dan masih sebatas mencari keuntungan. Sehingga tidak mendorong untuk pengungkapan CSR yang lebih luas. Hal ini mengakibatkan pengungkapan CSR masih sebatas memenuhi regulasi sebagai fungsi public relastion saja.
\end{abstract}

Kata Kunci: Struktur Kepemilikan, Kepemilikan Institutional, Kepemilikan Manajerial,

Kepemilikan Asing, Pengungkapan CSR, Nilai Perusahaan.

\begin{abstract}
The research aims to examine the effect of institutional ownership, managerial ownership and foreign ownership on firm value with corporate social responsibility disclosure as an mediating variable. The population of this research is the textile and garment sectors companies listed on the Indonesia Stock Exchange (IDX) in 2015 until 2019. The sampling technique using purposive sampling method, so that the number of samples is 50 sample. Further this study uses data analysis through multiple linear regressions with two steps using by SPSS version 16. The result showed that ownership structure has an effect on the CSR disclosure simultaneously, other result show that ownership structure has no effect on CSR disclosure partially. The result also shows that ownership structure and CSR disclosure have affect on firm value simultaneously. Than while partially institutional ownership and foreign ownership have negative impact on firm value. Meanwhile managerial ownership and CSR disclosure has no effect on firm value, and CSR disclosure is not an mediating of structure ownership on firm value. The result show that ownership structure has not been operation according with firms goals and just to profit. So it does not make CSR disclosure more broader. Then made CSR disclosure just to regulation as public relastion.
\end{abstract}

Keywords: Structure Ownership, Institutional Ownership, Managerial Ownership, Foreign Ownership, CSR Disclosure, Firm Value.

Naskah diterima : 28-02-2021, Naskah dipublikasikan : 30-04-2021 


\section{PENDAHULUAN}

Persaingan perdagangan dalam sebuah buah negara memiliki dampak meningkatnya perekonomian di negara itu sendiri. Akibatnya perusahaan harus siap untuk bersaing dengan kompetitornya dengan cara mengembangkan untuk perluasan pasar demi keberlangsungan hidup dan nilai perusahaannya. Demi tercapai tingginya nilai perusahaan, kebutuhan akal modal merupakan salah satu penyebab yang mempengaruhi nilai perusahaan dan keperluan akan modal ini sangat diperlukan peran para investor mulai dari investor manajemen, investor institusional dan investor asing, peran investor selain menjadi sumber modal juga berperan untuk meminimalisir agency problem, Menurut Linda dan Nyoman $(2019 ; 6101)$ untuk mengurangi biaya keagenan terdapat beberapa alternatif diantaranya dengan kepemilikan saham oleh manajer. Selain peran dari ketiga elemen itu juga sangat diperlukan hubungan sosial dengan masyarakat (corporate social responsibilty) guna mengimplementasikan tanggung jawab perusahaannya yang telah diatur dalam UU No.40 tahun 2007 tentang Perseroan Terbatas (PT) pasal 74, Peraturan Pemerintah (PP) No. 47 Tahun 2012 tentang Tanggung Jawab Sosial dan Lingkungan Perseroan Terbatas, dan Pasal 6 PP 47/2012 yang menjelaskan bahwa pelaksanaan CSR dimuat dalam laporan tahunan perseroan dan dipertanggungjawabkan kepada Rapat Umum Pemegang Saham (RUPS).

Berdasarkan hasil penelitian Riset Centre for Governance Institutions, and Organizations National University of Singapore (NUS) Business School pada tahun 2016, menunjukkan bahwa peringkat kualitas tanggung jawab sosial dari 100 perusahaan dengan sampel 4 negara yaitu Malaysia, Singapura, Thailand dan Indonesia diketahui posisi pertama Thailand dengan skor 56,8, posisi kedua Singapura dengan skor 48,8, posisi ketiga Indonesia dengan skor 48,4, dan Malaysia dengan skor 47,7 menempati posisi keempat. Hal ini menunjukkan bahwa Indonesia masih membutuhkan akan adanya perbaikan kualitas tanggung jawab sosial yang harus dilakukan oleh perusahaan (cnnindonesia.com). Kemudian kasus di Indonesia perusahaan yang melanggar praktik CSR adalah pabrik tekstil Indobarat. PT Indobarat pada tahun 2017 terkena kasus tindak pidana pencemaran lingkungan hidup karena limbahnya yang mencemari Sungai Kalimati Desa Cilangkap, Kecamatan Babakancikao, Kabupaten Purwakarta. Akibat tindakan kecerobohannya PT Indobarat di kenai denda sebesar 2 miliar dan mengembalikan kembali kondisi Sungai yang tercemari lembah dari operasional perusahaannya (Kompas.com).

Kasus serupa juga terjadi tahun 2017 pada PT Rayon Utama Makmur Sukoharjo, dengan keberadaan pabrik yang merupakan anak perusahaan dari PT Sri Rejeki Isman Tbk alias Sritex mengakibatkan warga dari empat desa di Kecamatan Nguter harus mencium bau busuk yang bikin mereka mual, pusing, dan produk utama berupa pakaian dan variannya. Dalam menjalankan tanggung jawab sosial perusahaan, perusahaan tekstil ini dengan menentukan aspek ekonomi, aspek sosial, aspek pendidikan dan aspek lingkungan. Berkat kinerja CSR yang baik tersebut PT Pan Brothers menjadi pemenang TOP CSR 2018 sektor industri tekstil yang diselenggarakan oleh Majalah Top Business dengan bekerja sama lembaga Komite Nasional Kebijakan Governance, Masyarakat CSR Indonesia, SGL Management, Asia Business Research Center, Mitra Bhadra Consulting, Yayasan PAEM, dan PPM manajemen (topbusiness.id).

Di samping itu PT Pan Brothers Tbk juga menorehkan kinerja yang memuaskan sepanjang tahun 2018. Dimana produsen ini berhasil meraih pertumbuhan baik dari segi topline maupun bottom line. Oleh karenanya, pada tahun 2018 mampu membukukan kenaikan laba bersih 107\% menjadi US\$ 16,2 juta dibandingkan 2017 (kontan.co.id). Penelitian yang mengkaji tentang strutur kepemilikan terhadap nilai perusahaan memperoleh hasil yang berbeda-beda seperti penelitian yang dilakukan Hasil penelitian Dewi et al, pada tahun (2017) menyatakan kepemilikan institusional dan kepemilikan manajerial tidak berpengaruh terhadap nilai perusahaan. dan Hasil penelitian Tandiontong \& Christian, pada tahun. (2019) bahwa kepemilikan manajemen, kepemilikan institusional berpengaruh signifikan terhadap nilai perusahaan. 
Penelitian yang dilakukan Sissandhy dan sudarno. (2014) Kepemilikan asing berpengaruh signifikan terhadap nilai perusahaan dan Hasil penelitian Anggraini \& Herlina . (2018) kepemilikan asing tidak memiliki pengaruh terhadap nilai perusahaan. Hasil penelitian Kim \& Lee. (2018) CSR memiliki hubungan positif terhadap nilai perusahaan dan Hasil penelitian Tandiontong \& Christian. (2019) CSR tidak berpengaruh terhadap nilai perusahaan. Hasil penelitian Edison. (2017) struktur kepemilikan asing, kepemilikan institusional, dan kepemilikan manajerial berpengaruh signifikan terhadap pengungkapan CSR, dan Hasil penelitian Zulvina et al. (2017) kepemilikan manajemen, kepemilikan asing berhubungan negatif terhadap CSR. Berdasarkan uraian diatas tujuan penelitian ini adalah untuk mengetahui dan menganalisis pengaruh langsung struktur kepemilikan terhadap nilai perusahaan dan pengaruh tidak langsung struktur kepemilikan terhadap nilai perusahaan dengan dimediasi varibel CSR

\section{KAJIAN LITERATUR Teori Keagenan}

Teori keagenan yang dikemukakan oleh Jensen, Michael dan Meckling (1976) mendefinisikan hubungan sebagai kontrak antara pemegang saham dan agen atau menjelaskan dua orang yang memiliki ikatan dalam suatu pekerjaan antara pemilik perusahaan dan manajemen. pemilik perusahaan menugaskan agennya untuk mengelola perusahaanya atas nama pemilik dengan imbalan yang telah disepakati. Teori keagenan ini muncul ketika pihak pemegang saham memperkerjakan orang lain untuk mengelola perusahaanya,dan teori agensi ini sebagai pembatas hubungan antara pemegang saham dengan agen yang mana pemegang saham memberikan wewenang kepada agen namun pemegang saham tidak boleh mencampuri urusan manajerial dalam operasi perusahaannya (Dewi dan Sanica 2017).

\section{Teori Legitimasi}

Teori legitimasi menurut Gray dan Kouhy (1995) adalah sebuah sistem pengolahan perusahaan yang mengedepankan keberpihakan dengan masyarakat (society), pemerintah, individu, dan kelompok masyarakat. Maka dari itu sistem yang diterapkan harus sesuai dengan harapan masyarakat sebagai wujud dari keberpihakan terhadap masyarakat. Utami dan Handoko (2018) menyatakan teori legitimasi memberikan penjelasan tentang pengungkapan tanggung jawab sosial dan lingkungan, dimana perusahaan terikat dengan kontrak sosial serta perusahaan harus setuju menjalankan operasinya sebagai aktivitas yang diinginkan secara sosial.

\section{Teori signaling}

Teori sinyal dicetuskan pertama kali oleh Michael Spence (1973) dalam penelitiannya yang berjudul Job Market Signalling. Teori ini membicarakan tentang informasi yang dipublikasikan sebagai pengumuman yang akan menarik sinyal kepada investor dalam pengambilan keputusan. Jika pengumuman itu membuat berita baik, maka pada waktu pengumuman diterima pasar diharapkan pasar akan bereaksi. Saat informasi diumumkan dan pelaku pasar telah menerima informasi itu, lalu pelaku pasar menginterpretasikan serta menganalisis informasi tersebut dengan pendapat individu masingmasing pelaku pasar sebagai signal yang baik (good news) ataukah buruk (bad news).

\section{Nilai Perusahaan (NP)}

Nilai perusahaan merupakan situasi tertentu yang telah dicapai oleh perusahaan sebagai gambaran dari respon balik dari masyarakat ke perusahaan yang berupa kepercayaan atas kinerja perusahaan semenjak didirikanya perusahaan hingga saat ini. Penilaian masyarakat terhadap suatu perusahaan salah satunya digambarkan pada meningkatnya harga saham. Menurut Purwanto dan Sulistyastuti (2017:18), mencari nilai perusahaan dengan melalui rasio, Price to Book Value (PBV) yakni dengan rumus sebagai berikut: 


$$
\text { PBV }=\frac{\text { Harga Pasar Persaham }}{\text { Nilai Buku }} \times 100 \%
$$

\section{Corporte Social Resposibility (CSR)}

Menurut Undang-Undang nomor 40 tahun 2007, CSR adalah komitmen perseroan untuk ikut serta dalam pembangunan ekonomi berkelanjutan guna meningkatkan taraf kehidupan dan lingkungan yang memiliki daya kemanfaatan dan kualitas yang tinggi bagi perseroan sendiri, komunitas setempat maupun masyarakat pada umumnya. Menurut (Munawaroh, 2014) CSR diukur dengan G4 diproksikan dengan CSDI, dalam penelitian ini diproksikan dengan perusahaan yang menerbitkan laporan keberlanjutan. Dalam penelitian ini CSR diukur menggunakan variabel dummy, yaitu:

Score 0 : jika perusahaan tidak mengungkapkan item pada daftar pernyataan

Score 1 : jika perusahaan mengungkapkan item pada daftar pernyataan.

Perhitungan indeks tingkat pengungkapan tanggung jawab sosial perusahaan diukur dengan rasio total skor yang diperoleh dengan skor maksimal yang diperoleh. Indeks diformulasikan sebagai berikut:

$$
\mathrm{CSR}=\frac{\mathrm{n}}{\mathrm{k}}
$$

Keterangan :

$\mathrm{n}$ : jumlah skor pengungkapan yang diperoleh untuk perusahaan.

$\mathrm{k}$ : jumlah skor maksimal 91 item (berdasarkan indikator pengungkapan CSR)

\section{Kepemilikan Institusional (KI)}

Kepemilikan institusional adalah hak milik atas perusahaan oleh institusi atau lembaga seperti perbankan, asuransi, perusahaan investasi dan lainya. Adapun rumus yang digunakan adalah sebagai berikut :

$$
\text { Institusional }=\frac{\begin{array}{c}
\text { Jumlah Saham yang } \\
\text { dimiliki Institusi }
\end{array}}{\text { Jumlah Saham Beredar }} \times 100 \%
$$

\section{Kepemilikan manajerial (KM)}

Kepemilikan manajerial adalah jumlah prosentase saham yang dimiliki pihak manajerial dari jumlah total modal saham perusahaan yang dikelola. Para agen ini menduduki posisi dewan komisaris dan dewan direksi perusahaan, para agen inipun memiliki latar belakang yang beda-beda, pertama, mereka mewakili pemegang saham institusi. Kedua, mereka adalah orang-orang profesional yang dipilih oleh pemegang saham dalam rapat umum pemegang saham. Ketiga, keagenan, di antara prinsipal dan agen sangat rentan akan terjadinya masalah keagenan (karima 2014).Rumus yang digunakan adalah sebagai berikut (Negara,2019):

$$
\text { K.manajerial }=\frac{\begin{array}{l}
\text { Jumlah Saham yang } \\
\text { dimiliki manajemen }
\end{array}}{\text { Jumlah Saham Beredar }} \times 100 \%
$$

\section{Kepemilikan Asing (KA)}

Dalam pasal 1 ayat 6 Undang-Undang Nomor 25 tahun 2007 menyatakan bahwa penanam modal asing adalah perseorangan atau warga negara asing, badan usaha asing, dan atau pemerintah asing yang melakukan penanaman modal pada wilayah negara Republik Indonesia. Kepemilikan asing adalah jumlah saham yang dimiliki oleh pihak asing (luar negeri) terhadap saham indonesia baik perorangan maupun lembaga institusi. (karima 2014) rumus perhitunganya merujuk penelitian Waryanto (2010) sebagai berikut:

$$
\text { K.Asing }=\frac{\begin{array}{c}
\text { Jumlah Saham yang } \\
\text { dimiliki Asing }
\end{array}}{\begin{array}{c}
\text { Jumlah Saham } \\
\text { Beredar }
\end{array}} \times 100 \%
$$




\section{PENGEMBANGAN HIPOTESI DAN KERANGKA PEMIKIRAN}

Edison (2017) dalam penelitiannya menemukan bahwa secara parsial dan simultan struktur kepemilikan institusional memiliki pengaruh signifikan terhadap pengungkapan CSR. Hal ini memiliki arti bahwa kepemilikan saham institusional dapat berperan dalam menentukan program CSR perusahaan yang akan diimplementasikan. Investor institusional memiliki power dan experience bertanggung jawab dalam menerapkan prinsip corporate governance untuk melindungi hak dan kepentingan seluruh pemegang saham, sehingga mereka menuntut perusahaan untuk melakukan komunikasi secara transparan.

H1 : Terdapat pengaruh kepemilikan institusional terhadap CSR.

Penelitian karima (2014) menyatakan bahwa kepemilikan manajerial memiliki pengaruh yang signifikan terhadap pengungkapan CSR. Modal yang ditanam manajer di perusahaan yang ia kelola memberikan dampak meningkatnya pengungkapan informasi pertanggungjawaban sosial (CSR) yang disebabkan meningkatnya kepemilikan manajemen, kepemilikan manajerial yang besar akan efektif dalam memonitoring aktivitas perusahaan. Oleh karenanya penulis mengambil hipotesis :

$\mathrm{H} 2$ : Terdapat pengaruh kepemilikan manajerial terhadap CSR.

Pradana dan suzan (2016) dalam penelitiannya menemukan bahwa kepemilikan asing secara simultan memiliki pengaruh terhadap pengungkapan CSR. Semakin besar persentase kepemilikan asing maka akan membuat pengaruh terhadap program kepedulian dengan masyarakat sekitar, dikarenakan kepemilikan asing lebih peduli dengan lingkungan sekitar yang tujuan jangka panjangnya untuk menjaga keseimbangan antara konflik perusahaan dan sosial. Oleh karenanya penulis mengambil hipotesis.

H3 : Terdapat pengaruh kepemilikan asing terhadap CSR

Wardani (2017) dan Kim.W.S et al (2018) yang menyatakan kepemilikan institusional memiliki pengaruh terhadap nilai perusahaan. Tingkat kepemilikan institusional yang tinggi memiliki dampak pada naiknya nilai perusahaan karena semakin tinggi tingkat kepemilikan institusional maka akan banyak yang memberikan monitoring terhadap kemajuan perusahaan. Oleh karenanya penulis mengambil hipotesis :

H4 : Terdapat pengaruh kepemilikan institusional terhadap nilai perusahaan.

Manajer yang sekaligus pemegang saham akan meningkatkan nilai perusahaan karena dengan meningkatkan nilai perusahaan juga akan meningkatkan nilai kekayaannya sebagai pemegang saham. Kepemilikan manajerial dalam penelitian ini dapat diukur dengan jumlah prosentase kepemilikan saham oleh manajer, komisaris, dan direksi. Nagara (2019). Dalam penelitian Widianingsih (2018)

H5 : Terdapat pengaruh kepemilikan manajerial terhadap nilai perusahaan.

Selain komposisi portofolio asing, manajerial perusahaan asing lebih fokus dan lebih efisien dalam mengarahkan operasionalnya sehingga dapat meningkatkan nilai perusahaan. Dalam penelitian (Rely dan Arsjah, 2018) kepemilikan asing mampu mempengaruhi nilai perusahaan jika persentase kepemilikannya tinggi sehingga hasil profit yang didapat dapat maksimal.

H6 : Terdapat pengaruh kepemilikan asing terhadap nilai perusahaan.

Corporate social responsibility adalah upaya yang dilakukan entitas bisnis untuk meminimalisir dampak negatif dan memaksimalkan dampak positif atas beroperasinya perusahaan terhadap seluruh pemangku kepentingan dalam ranah ekonomi, sosial, dan lingkungan agar mencapai tujuan pembangunan berkelanjutan dan juga nilai perusahaan yang baik (Rachman dkk, $2011: 15$ ).

H7 : Terdapat pengaruh CSR terhadap nilai perusahaan. 


\section{JURNAL AKUNTANSI, Vol. 10, No. 1, April (2021)}

Chandrarin, Rahman (2017) yang menemukan bahwa kepemilikan institusional memiliki pengaruh positif terhadap nilai perusahaan. Kepemilikan institusional dapat memaksimalkan aktiva perusahaan dan juga diharapkan dapat bertindak mencegah pemborosan pihak manajemen. semakin tinggi kepemilikan institusional maka akan memperketat pengawasan terhadap manajerial dan dapat mengurangi opportunistic manajer yang nantinya memiliki dampak pada meningkatnya nilai perusahaan.

H8 : Terdapat pengaruh kepemilikan institusional terhadap nilai perusahaan melalui CSR.

Corporate social responsibility memberikan efek jangka panjang terhadap perusahaan, yang nantinya akan mendapatkan legitimasi dari masyarakat terhadap kinerja perusahaan. perusahaan yang mendapatkan legitimasi masyarakat akan lebih mudah meningkatkan nilai perusahaannya karena lebih dikenal oleh masyarakat dibandingkan perusahaan yang tidak mengungkapkan (hartana dan putra 2017)

H9 : Terdapat pengaruh kepemilikan manajerial terhadap nilai perusahaan melalui CSR.

Pradana dan Susan (2016) bahwa kepemilikan asing secara simultan memiliki pengaruh terhadap pengungkapan CSR hal ini dikarenakan semakin tinggi tingkat kepemilikan asing akan mempengaruhi seberapa banyak dan program apa yang akan dilaksanakan, dan juga dilatarbelakangi oleh pihak asing yang lebih tertarik dengan perusahaan yang tingkat pengungkapan CSR tinggi dikarenakan hal sedemikian ini akan mempengaruhi nilai perusahaan dimasa mendatang.

H10 : Terdapat pengaruh kepemilikan asing terhadap nilai perusahaan melalui CSR

Berdasarkan uraian diatas, dapat dibuat kerangka berfikir teoritis yang menggambarkan hubungan antara variabel dalam penelitian ini, yaitu:

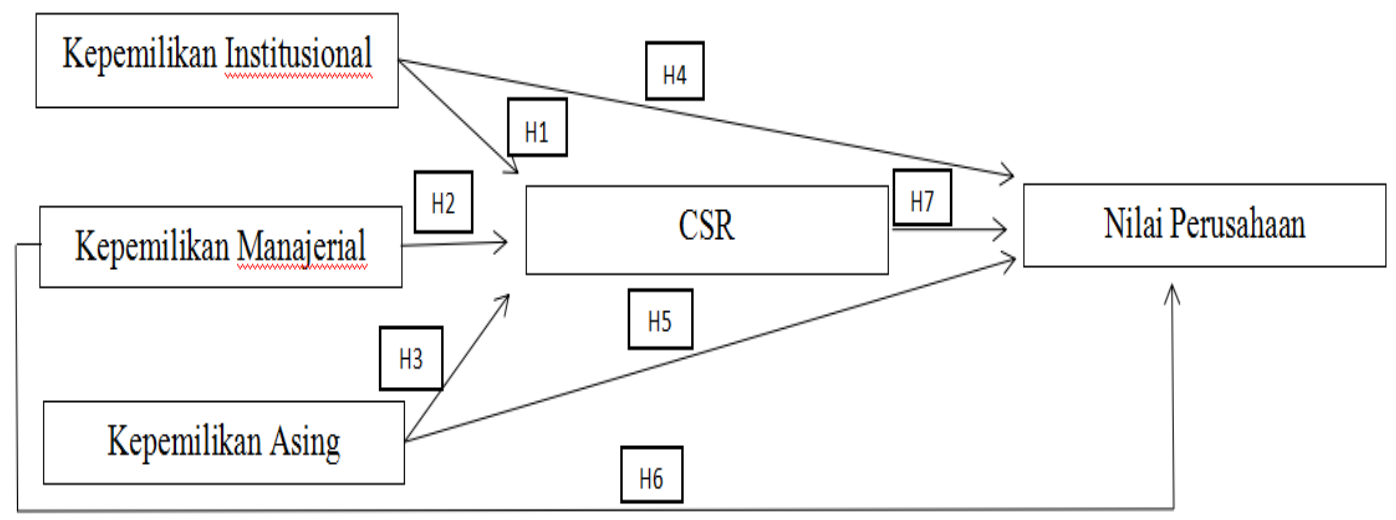

Gambar 1. Kerangka Pemikiran

\section{METODE PENELITIAN}

Penelitian ini dilakukan pada perusahaan tekstil dan garmen yang terdaftar di Bursa Efek Indonesia (BEI) dan yang menyampaikan informasi laporan keuangannya melalui situs resmi masingmasing perusahaannya di www.idx.co.id. Populasi dalam penelitian ini adalah perusahaan tekstil dan garmen pada tahun 2015-2019. Untuk pengambilan sampel penelitian ini menggunakan metode purposive sampling dengan kriteria-kriteria yang tertera pada tabel.1. 
Tabel 1. Kriteria Penentuan Sampel

\begin{tabular}{|c|l|c|}
\hline No & \multicolumn{1}{|c|}{ Kriteria } & Jumlah \\
\hline 1 & $\begin{array}{l}\text { Industri tekstil dan garmen yang terdaftar di bursa efek Indonesia pada } \\
\text { periode 2015-2019 }\end{array}$ & 21 \\
\hline 2 & $\begin{array}{l}\text { Industri tekstil dan garmen yang tidak mempublikasikan laporan } \\
\text { keuangannya selama periode pengamatan. }\end{array}$ & $(4)$ \\
\hline 3 & $\begin{array}{l}\text { Industri tekstil dan garmen yang tidak mengungkapkan data-data berkaitan } \\
\text { dengan variabel penelitian dan tersedia dengan lengkap }\end{array}$ & $(7)$ \\
\hline \multicolumn{2}{|l|}{ Tumlah perusahaan yang masuk kriteria } & 10 \\
\hline \multicolumn{2}{|l|}{ Total data selama 5 tahun (10x5) } & 50 \\
\hline
\end{tabular}

Sumber :data diolah 2020

Model penelitian ini adalah sebagai berikut:

$$
\begin{array}{|l|}
Y_{1}=\alpha_{1}+b Y_{1} X_{1}+b Y_{1} X_{2}+b Y_{1} X_{3}+e_{1} \\
\hline Y_{2}=\alpha_{2} b y_{2} X_{1}+b Y_{2} X_{2}+b Y_{2} X_{3}+b Y_{1} Y_{2}+e 1 \\
\hline
\end{array}
$$

Keterangan :

$\mathrm{Y} 1=\mathrm{CSR}$

$\mathrm{Y} 2=$ nilai perusahaan

$\mathrm{X} 1=$ Kepemilikan Institusional

$\mathrm{X} 2=$ Kepemilikan manajemen

X3 = Kepemilikan Asing

e1 $=$ Residual Error

$\alpha=$ Konstanta

$\mathrm{b}=$ Koefisien regresi

Keputusan menerima atau menolak hipotesis yang diajukan dilakukan dengan syarat sebagai berikut :

Jika thitung > ttabel maka hipotesis nol (H0) ditolak atau Ha diterima, artinya terdapat pengaruh antaradua variabel secara statistik.

Jika thitung < ttabel maka hipotesis nol (H0) diterima atau Ha ditolak, artinya tidak terdapat pengaruhantara dua variabel secara statistik.

Sedangkan untuk dasar pengambilan keputusan menurut Herlina dan Diputra (2018:21) dalam signifikansi berpengaruh langsung tidaknya dengan cara melakukan perhitungan nilai $t$ dari koefisien ab terlebih dahulu dengan rumus :

$$
\mathrm{t}=\frac{\mathrm{Ab}}{\mathrm{S}_{\mathrm{ab}}}
$$

Selanjutnya hasil nilai dari t hitung dibandingkan dengan nilai $t$ tabel. Apabila hasil dari nilai $\mathrm{t}$ hitung lebih besar dari nilai $\mathrm{t}$ tabel (thitung $>\mathrm{t}$ tabel) maka dapat disimpulkan bahwa terjadi pengaruh mediasi. 


\section{HASIL DAN PEMBAHASAN}

berdasarkan hasil analisis deskriptif variabel KI, KM, KA, CSR dan NP maka dapat dijelaskan pada tabel berikut:

Tabel 2. Hasil Uji Statistik Deskriptif

\begin{tabular}{|c|c|c|c|c|}
\hline Variabel & Minimum & Maximum & Mean & Std. Deviation \\
\hline KI & 0,00000 & 0,96000 & 0,4276000 & 0,25248609 \\
\hline KM & 0,00000 & 0,24200 & 0,0119600 & 0,03573768 \\
\hline Variabel & Minimum & Maximum & Mean & Std. Deviation \\
\hline KA & 0,00000 & 0,76700 & 0,2352400 & 0,27562904 \\
\hline CSR & 0,02198 & 0,35165 & 0,1474725 & 0,10101135 \\
\hline Y & 0,13000 & 26,14000 & 4,7860000 & 7,74605996 \\
\hline
\end{tabular}

Sumber : hasil olah data dengan SPSS, 2020

Berdasarkan tabel 1.2 dapat diketahui output dari uji statistik deskriptif menunjukkan bahwa jumlah data observasi (n) dalam penelitian ini adalah sebanyak 50 data. Dimana dari 50 data tersebut rata-rata variabel independen Kepemilikan Institusional (KI) dalam periode pengamatan tahun 2015-2019 sebesar 0,4276 dengan nilai standar deviasi 0,2524. dan nilai minimum sebesar 0,0000 , sedangkan maksimalnya sebesar 0,9600 . Kepemilikan manajerial memiliki standar deviasi 0,0357 dengan nilai rata-rata sebesar 0,0119 . dan nilai maksimum sebesar 0,2420 serta nilai minimumnya adalah 0,000 . Nilai rata-rata kepemilikan saham oleh asing adalah sebesar 0,2352 dengan nilai standar deviasi yang dimiliki adalah sebesar 0,2756. Sedangkan untuk nilai masingmasing maksimum dan minimumnya masing-masing dari variabel ini adalah 0,7670 dan 0.0000. CSR memiliki nilai rata-rata 0.1474 dengan standar deviasi yang dimilikinya adalah sebesar 0.1010 . dan untuk nilai minimumnya 0.0219 dan maksimumnya yaitu sebesar 0.3516 . Variabel nilai perusahaan pada industri tekstil dan garmen yang terdaftar di Bursa Efek Indonesia tahun 20152019 nilai rata-ratanya adalah sebesar 4.7860 dengan standar deviasi yang dimiliki 7.7460. Untuk nilai maksimum dan minimumnya dari variabel nilai perusahaan adalah sebesar 0.1300 dan 7.7460 .

\section{ANALISIS REGRESI}

\section{Uji Koefisien Determinasi}

Uji Koefisien Determinasi (CSR)

Tabel 3. Hasil Uji Koefisien Determinasi (CSR)

\begin{tabular}{|c|c|c|c|}
\hline \multicolumn{1}{|c|}{ Variabel } & R & R Square & Adjusted R Square \\
\hline KM, KI, KA & 0,254 & 0,064 & 0,003 \\
\hline
\end{tabular}

Sumber : hasil olah data dengan SPSS, 2020

Berdasarkan output tabel hasil uji koefisien determinasi menunjukkan bahwa besarnya $\mathrm{R}$. Square adalah 0.064 atau sebesar 6,4\%. Hal ini berarti variabel kepemilikan institusional, kepemilikan manajerial dan kepemilikan asing memiliki kontribusi atau untuk menjelaskan CSR sebesar 6,4 \% terhadap Corporate Social Responsibility. Sedangkan untuk sisanya yaitu 93,6 \% dipengaruhi oleh variabel lain yang ada di luar model penelitian ini. 
Uji Koefisien Determinasi (NP)

Tabel 4. Hasil Uji Koefisien Determinasi (Y)

\begin{tabular}{|c|c|c|c|}
\hline \multicolumn{1}{|c|}{ Variabel } & R & R Square & Adjusted R Square \\
\hline KM, KI, KA, CSR & 0.505 & 0.255 & 0.189 \\
\hline
\end{tabular}

Sumber : hasil olah data dengan SPSS, 2020

Dari output regresi pada tabel di atas diperoleh R Square sebesar 0.255 atau sebesar $25.5 \%$. Hal ini menunjukkan bahwa variabel kepemilikan institusional, kepemilikan manajemen, kepemilikan asing, dan CSR memiliki pengaruh atau kontribusi sebesar $25.5 \%$ terhadap nilai perusahaan yang dilakukan oleh industri tekstil dan garmen yang terdaftar di Bursa Efek Indonesia dari tahun 2015 sampai dengan 2019. Kemudian untuk sisanya sebesar $74.5 \%$ nilai perusahaan dipengaruhi oleh faktor lain diluar variabel yang diteliti.

\section{Uji Simultan (Uji F)}

Dasar pengambilan keputusan untuk Uji F yakni apabila Fhitung < Ftabel dengan probabilitas signifikansinya $>0.05$, maka variabel independen tidak berpengaruh secara simultan dengan variabel dependen. Berlaku juga sebaliknya, Jika Fhitung > Ftabel dengan probabilitas signifikansinya $<0.05$, maka semua variabel independen berpengaruh secara simultan dengan variabel dependen dalam penelitian tersebut, hasil regresi dependen CSR sebaai berikut:

Tabel 5. Uji F (CSR)

\begin{tabular}{|l|l|l|l|l|l|l|}
\hline $\begin{array}{l}\text { Dependen } \\
\text { t }\end{array}$ & Independet & F Tabel & F hitung & Sig. & p - value & Keterangan \\
\hline CSR & KI, KM, KA & 2.81 & 3.157 & 0,032 & $\mathrm{p}<0,05$ & Model Fit \\
\hline
\end{tabular}

Sumber : hasil olah data dengan SPSS, 2020

Dari hasil uji simultan di atas, dapat terlihat bahwa nilai F hitung yang diperoleh sebesar 3,157 yang berarti lebih besar dari F Tabel 2.81, dengan nilai signifikansi 0.032 yang lebih kecil dari 0.05 . Dengan demikian maka dapat disimpulkan bahwa kepemilikan institusional, kepemilikan manajemen, dan kepemilikan asing secara simultan berpengaruh terhadap pengungkapan CSR pada sektor industri tekstil dan garmen. Dan dependen Nilai Perusahaan sebagai berikut:

Tabel 6. Uji F (NP)

\begin{tabular}{|l|l|l|l|l|l|l|}
\hline Dependent & Independet & F Tabel & F hitung & Sig. & p - value & Keterangan \\
\hline NP & KI,KM,KA,CSR & 2.58 & 3.853 & 0,009 & $\mathrm{p}<0,05$ & Model Fit \\
\hline
\end{tabular}

Sumber : hasil olah data dengan SPSS, 2020

Berdasarkan Tabel 6 dapat dilihat nilai F hitungnya adalah 3.852, lebih besar dari F tabel 2.58 dengan signifikansi 0.009 lebih kecil dari 0.05, sehingga dapat disimpulkan bahwa variabel kepemilikan institusional, kepemilikan manajer, kepemilikan asing dan CSR secara bersama-sama memiliki pengaruh terhadap nilai perusahaan.

\section{Uji Parsial (Uji T)}

Untuk dasar pengambilan keputusannya yakni apabila thitung < ttabel, dengan probabilitas signifikansinya $>0,05$, maka variabel independen tidak memiliki pengaruh terhadap variabel dependen. Sedangkan jikalau thitung $>$ ttabel dengan probabilitas signifikansinya $<0$, 05, maka variabel independen memiliki pengaruh terhadap variabel dependen. 
JURNAL AKUNTANSI, Vol. 10, No. 1, April (2021)

Tabel 7. UJI T (CSR)

\begin{tabular}{|l|l|l|l|l|}
\hline \multirow{3}{*}{ Variabel Independen } & \multicolumn{4}{c|}{ CSariabel Dependen } \\
\cline { 2 - 5 } & \multicolumn{4}{|c|}{ CSR } \\
\cline { 2 - 5 } & Coefficient & t statistic & Keterangan \\
\hline Panel Model Penelitian & & & & \\
\hline (Constant) & 0.200 & 4.570 & 0.000 & - \\
\hline KI & -0.061 & -0.866 & 0.391 & H1 ditolak \\
\hline KM & -0.453 & -1.122 & 0.268 & H2 ditolak \\
\hline KA & -0.088 & -1.360 & 0.181 & H3 ditolak \\
\hline
\end{tabular}

Sumber : hasil olah data dengan SPSS, 2020

Dari hasil persamaan model pertama dengan regresi Z (CSR) dapat dijelaskan bahwa nilai konstantanya adalah sebesar 0.200. Hal ini menjelaskan bahwa disaat variabel independen Kepemilikan Institusional (KI), Kepemilikan manajerial (KM), dan Kepemilikan Asing (KA) dianggap dengan nol (0), maka nilai CSR mengalami peningkatan sebesar 0.200.

Berdasarkan hasil estimasi regresi kepemilikan institusional memiliki nilai koefisien regresi sebesar -0,061 dengan tingkat signifikansi 0.391 yang berarti lebih besar dari $\alpha=0,05(0,391>0,05)$ dan thitung sebesar $-0,866$ lebih kecil dari ttabel $(-0,866<1.67866)$. Dengan demikian kepemilikan institusional tidak memiliki pengaruh terhadap CSR. Sehingga dapat disimpulkan hipotesis pertama (H1) yang menyatakan kepemilikan institusional berpengaruh terhadap CSR ditolak. Hasil penelitian ini menunjukkan bahwa besar kecilnya ukuran kepemilikan saham oleh institusi yang dimiliki oleh sektor industri tekstil dan garmen tidak mempengaruhi terhadap tinggi rendahnya pengungkapan CSR pada perusahaan. Hal ini mengindikasikan bahwa kepemilikan institusional tidak mendorong pengungkapan CSR untuk tumbuh dan berkembang dalam perusahaan, sehingga menyebabkan tidak memiliki pengaruh terhadap CSR. Menurut Eriandani (2013) pemilik saham institusional yang menanamkan sahamnya pada perusahaan memiliki berbagai macam tujuan dan harapan yang berbeda antara satu institusi dengan institusi yang lain dalam menempatkan dirinya sebagai investor perusahaan. Sehingga hal ini akan mengakibatkan kurang optimalnya dorongan bagi perusahaan untuk melakukan praktek CSR dengan maksimal.

Dari hasil estimasi antara variabel kepemilikan manajerial dengan CSR diperoleh thitung sebesar -1.122 yang berarti nilai thitung $-1.122<$ ttabel 1.67866 , serta hasil signifikansinya 0,268 lebih besar dari $\alpha=0,05$. Hal ini memiliki arti bahwa kepemilikan manajerial tidak memiliki pengaruh terhadap CSR. Yang berarti besar kecilnya kepemilikan saham oleh manajer tidak mempengaruhi CSR pada perusahaan. Dengan demikian hipotesis kedua (H2) yang menyatakan kepemilikan manajerial memiliki pengaruh terhadap CSR ditolak. Menurut Sukirni (2012) kepemilikan saham oleh investor manajer yang relatif kecil dan dengan tingkat persentase yang sama menjadikan kepemilikan saham oleh manajerial tidak mempengaruhi terhadap luas pengungkapan CSR yang dilakukan oleh perusahaan. Alasan lain menurut Ardianti et al (2019) tidak berpengaruhnya kepemilikan manajerial terhadap CSR dapat disebabkan oleh belum terselesaikannya antara kepentingan yang dimiliki oleh manajer dengan kepentingan yang diharapkan oleh pemegang saham. Sehingga membuat enggan pihak manajer untuk menanamkan sahamnya pada perusahaan yang dipimpinya. Dengan demikian mengakibatkan tingkat kepemilikan manajer relative sedikit dan sulit untuk memprediksi pengaruhnya terhadap CSR perusahaan.

Variabel kepemilikan asing memiliki nilai signifikansi 0,181 lebih besar dari $\alpha=0.05(0,181>$ $0,05)$ dengan nilai koefisien regresi $-0,088$, dan thitung sebesar -1.360 lebih kecil dari ttabel $(-1,360<$ 1.67866). Dengan demikian hipotesis ketiga (H3) yang menyatakan kepemilikan asing berpengaruh terhadap CSR ditolak. Artinya jumlah kepemilikan saham oleh institusi yang besar tidak mampu meningkatkan CSR pada perusahaan. Hal ini mengandung arti bahwa dari besar kecilnya proporsi 


\section{JURNAL AKUNTANSI, Vol. 10, No. 1, April (2021)}

kepemilikan saham oleh asing pada sebuah perusahaan, tidak dapat memberikan pengaruh terhadap luas atau tidaknya tingkat pengungkapan CSR di dalam laporan keuangan yang dilaporkan oleh perusahaan.

Ketidakpengaruhan kepemilikan asing terhadap pengungkapan CSR dalam penelitian ini dapat disebabkan oleh data yang dihimpun dari variabel kepemilikan asing pada industri tekstil dan garmen cenderung masih rendah yaitu dengan rata-rata sebesar 0,23. Disamping itu juga terdapat beberapa perusahaan yang tidak ada pemilik saham asing sama sekali diantaranya Industri Sri Rejeki Isman Tbk dan Stra Petrochem Tbk selama periode pengamatan. Ketidakpengaruhan kepemilikan asing yang disebabkan oleh masalah rendahnya data juga dibenarkan oleh Rahmah (2015) yang mengungkapkan bahwa kepemilikan asing tidak mempengaruhi luasnya pengungkapan CSR karena disebabkan oleh rata-rata perusahaan yang menjadi sampel dalam penelitian ini didominasi oleh perusahaan yang jumlah saham asingnya tidak besar.

Tabel 8. Uji $\mathrm{T}(\mathrm{NP})$

\begin{tabular}{|l|l|l|l|l|}
\hline \multirow{2}{*}{ Variabel Independen } & \multicolumn{4}{|c|}{ Variabel Dependen } \\
\cline { 2 - 5 } & \multicolumn{4}{|c|}{ Nilai Perusahaan } \\
\cline { 2 - 5 } & Coefficient & t statistic & Sig & Keterangan \\
\hline Panel Model Penelitian & & & & \\
\hline (Constant) & 14.355 & 3.933 & 0.000 & - \\
\hline KI & -9.062 & -1.831 & 0.074 & H4 diterima \\
\hline KM & -32.846 & -1.160 & 0.252 & H5 ditolak \\
\hline KA & -17.137 & -3.740 & 0.001 & H6 diterima \\
\hline CSR & -8.608 & -844 & 0.403 & H7 ditolak \\
\hline
\end{tabular}

Sumber : hasil olah data dengan SPSS, 2020

Persamaan model di atas dapat dijelaskan bahwa nilai konstanta sebesar 14.355. Ini menjelaskan jika variabel independen kepemilikan institusional, kepemilikan manajemen, kepemilikan asing dan CSR dianggap dengan nol (0), maka nilai perusahaan mengalami peningkatan sebesar 14.355.

Berdasarkan hasil estimasi regresi kedua diantara variabel kepemilikan institusional dengan nilai perusahaan diperoleh koefisien regresinya dengan arah negatif sebesar $-9,062$, dengan thitung sebesar -1.831 yang berarti nilai hitung $-1.831>$ ttabel 1.65251 , serta hasil signifikansinya sebesar $0,074>0,05$. Hal ini menunjukkan bahwa kepemilikan institusional memiliki pengaruh negatif terhadap nilai perusahaan tetapi tidak signifikan. Dengan demikian hipotesis keempat (H4) yang menyatakan kepemilikan institusional berpengaruh terhadap nilai perusahaan diterima. yakni kepemilikan saham oleh institusional memiliki pengaruh negatif dan signifikan terhadap nilai perusahaan pada industri tekstil dan garmen di Bursa Efek Indonesia (BEI) periode 2015-2019. Hal ini mengindikasikan bahwa keberadaan investor institusional yang semakin banyak akan berdampak terhadap menurunnya nilai perusahaan yang disebabkan oleh mekanisme tata kelola perusahaan yang belum berjalan dengan maksimal.

Berdasarkan data penelitian yang digunakan masing-masing dari variabel struktur kepemilikan memiliki rata-rata sebesar 42,76 \% untuk kepemilikan institusional, $0.12 \%$ untuk kepemilikan manajerial dan 23,52\% untuk kepemilikan saham oleh asing. Dari data ini menunjukkan bahwa kepemilikan institusional sebagai pemegang saham mayoritas dalam perusahaan apabila disalahgunakan dapat memiliki kecenderungan untuk berpihak kepada manajerial perusahaan tanpa memperhatikan kepentingan pemegang saham minoritas lainnya. Sehingga hak atas pengawasan dan pengendalian terhadap operasional manajerial yang dimilikinya tidak berjalan dan mengakibatkan kepemilikan institusional berpengaruh negatif terhadap nilai perusahaan. 


\section{JURNAL AKUNTANSI, Vol. 10, No. 1, April (2021)}

Koefisien regresi kepemilikan manajerial sebesar -32.846 dengan nilai signfikasnsi 0,252 lebih besar dari $\alpha=0,05(0,252>0,05)$ dan thitung sebesar -1.160 lebih kecil ttabe (1.6794). Dengan demikian kepemilikan manajerial tidak memiliki pengaruh terhadap nilai perusahaan. Yang berarti besar kecilnya kepemilikan saham oleh manajer tidak mempengaruhi nilai perusahaan. Menurut Siregar dan Pambudi (2017) juga menjelaskan tidak berpengaruhnya kepemilikan manajerial terhadap nilai perusahaan dapat disebabkan oleh manajer yang cenderung untuk mementingkan kepentingan diri sendiri dan enggan untuk bekerja secara optimal sesuai tujuan perusahaan. Hal ini dipicu dengan kondisi perusahaan tekstil dan garmen saat ini yang sedang dilanda kesulitan dalam operasionalnya. Dimana dengan hadirnya kebijakan baru yang menghapuskan masalah regulasi terkait kemudahan impor pada tujuan ekspor akan menambahkan biaya pajak yang lebih besar bagi perusahaan dan ditambah lagi dengan bahan baku untuk produksi yang harganya naik. Sehingga dengan keadaan yang sedemikian menjadikan mereka memiliki anggapan tidak akan dapat bekerja secara efisien dan efektif untuk keluar dari permasalahan tersebut guna meningkatkan nilai perusahaan. Dampaknya harga saham akan turun dan dan bermuara pada menurunnya nilai perusahaan karena keuntungan yang minim dan lepas tangannya manajemen.

Variabel kepemilikan asing koefisien regresinya sebesar -17.137 dengan tingkat signifikansi 0,001 lebih kecil dari $\alpha=0,05(0,001<0,05)$ dan thitung sebesar $-3,740$ lebih besar dari ttabel $(-3,740>$ 1.6794). Dengan demikian hipotesis keenam (H6) yang menyatakan kepemilikan asing memiliki pengaruh terhadap nilai perusahaan diterima. Artinya dengan jumlah kepemilikan saham oleh asing yang besar dapat mempengaruhi menurunnya nilai perusahaan. Hal ini ditunjukkan dengan nilai koefisien regresi yang dimilikinya berarah negatif. Hasil penelitian ini memberikan bukti empiris bahwa industri tekstil dan garmen yang sahamnya dimiliki oleh investor asing belum dapat melaksanakan pengendalian dan pengawasan yang optimal dalam menciptakan terwujudnya tata kelola perusahaan yang maksimal untuk meningkatkan nilai perusahaan yang tinggi sehingga dengan tingginya proporsi kepemilikan saham oleh asing mengakibatkan nilai perusahaan menurun, berlaku juga dengan sebaliknya.

Santi et al (2017) menjelaskan bahwa pengaruh negatif dari variabel kepemilikan saham oleh investor asing terhadap nilai perusahaan dapat disebabkan karena lemahnya counterpart dari investor lokal. Sehingga hal ini mengakibatkan investor asing kuat dan cenderung mendorong terjadinya perubahan arah harga saham yang mengikuti kepemilikan saham asing. Sehingga hal ini cenderung menarik investor lokal untuk mengikuti aksi investor asing baik ketika transaksi pembelian maupun melakukan transaksi penjualan. Sehingga hal ini akan mengakibatkan nilai perusahaan menurun.

Variabel CSR memiliki nilai koefisien regresi sebesar -8,608 dengan nilai signifikansi 0,403 lebih besar dari $\alpha=0,05(0,403>0,05)$. Dan thitung sebesar $-0,844$ lebih kecil dari ttabel $(-0,844<$ 1.6794). Dengan demikian CSR tidak memiliki pengaruh terhadap nilai perusahaan. Hal ini memiliki makna bahwa tinggi rendahnya CSR belum tentu dapat meningkatkan nilai perusahaan Hal ini mengindikasikan bahwa luas tidaknya pengungkapan CSR yang disampaikan dalam laporan tahunan oleh perusahaan tidak berpengaruh terhadap tinggi rendahnya nilai perusahaan pada industri tekstil dan garmen.

Berdasarkan Undang-undang Perseroan Terbatas Nomor 40 Tahun 2007, Pasal 74 telah dijelaskan terkait kewajiban perseroan yang menjalankan kegiatan usahanya dibidang atau berkaitan dengan Sumber Daya Alam (SDA) untuk melaksanakan tanggung jawab sosial dan lingkungan. Dari industri tekstil dan garmen yang menjadi sampel dalam penelitian ini secara keseluruhan telah memenuhi ketentuan ini untuk menginformasikan kegiatan CSR dalam laporan tahunan. Namun pengungkapan tersebut ternyata masih sebatas formalitas dan sukarela. Hal ini dapat dibuktikan dengan data penelitian dari variabel CSR yang cenderung masih sedikit, yaitu dengan rentan antara 2,1\% sampai dengan $35,1 \%$ dan rata-rata $14,7 \%$, sehingga pengaruh CSR terhadap nilai perusahaan tidak dapat diketahui. Hal ini dibenarkan oleh Polii dan Herawaty (2020) yang menemukan bahwa CSR tidak 


\section{JURNAL AKUNTANSI, Vol. 10, No. 1, April (2021)}

mempengaruhi nilai perusahaan, dikarenakan pengungkapan CSR yang masih rendah dan hanya sebatas sebagai fungsi public relation.

Dari hasil pengujian hipotesis yang menyatakan bahwa terdapat pengaruh kepemilikan institusional, manajerial dan asing terhadap nilai perusahaan melalui CSR ditolak karena dari hasil analisis jalur menunjukkan hasil bahwa variabel CSR selaku variabel mediating dinilai tidak memediasi hubungan antara kepemilikan saham oleh institusional, manajemen, asing terhadap nilai perusahaan. Hal ini mengindikasikan bahwa kepemilikan saham oleh institusional tidak dapat meningkatkan nilai perusahaan yang didukung oleh keberadaan CSR pada industri tekstil dan garmen. Purbopangestu \& Subowo, (2014) menjelaskan variabel mediating CSR yang dinilai tidak memediasi hubungan antara kepemilikan saham oleh institusi terhadap nilai perusahaan dapat disebabkan karena investor institusional dalam menanamkan sahamnya hanya untuk menginginkan keuntungan dalam jangka pendek yakni laba tanpa memperhatikan nilai perusahaan dan CSR karena mereka beranggapan melaksanakan program CSR hanya mengurangi laba perusahaan saja.

Menurut Baron dan Kenny (1986) untuk menentukan ada tidaknya pengaruh mediasi dalam sebuah hubungan terdapat tiga kriteria dari hasil persamaan yang harus terpenuhi yakni untuk variabel independen harus memiliki pengaruh signifikan terhadap variabel mediating, kemudian dalam persamaan regresi kedua variabel independen juga harus memiliki pengaruh signifikan terhadap variabel dependen. Dalam persamaan regresi ketiga variabel mediasi juga harus memiliki pengaruh signifikan terhadap variabel dependen. Sedangkan dari hasil estimasi regresi dalam penelitian ini menunjukkan bahwa struktur kepemilikan tidak memiliki pengaruh terhadap CSR maupun terhadap nilai perusahaan dan CSR juga terbukti tidak memiliki pengaruh terhadap nilai perusahaan. Sehingga hal ini tidak memenuhi kriteria untuk menentukan ada tidaknya pengaruh mediasi dari variabel CSR dalam hubungan kepemilikan saham oleh manajer dengan nilai perusahaan.

\section{PENUTUP}

\section{Simpulan}

Kepemilikan institusional, kepemilikan manajerial dan kepemilikan asing tidak berpengaruh terhadap CSR pada perusahaan tekstil dan garment yang terdaftar di Bursa efek Indonesia (BEI) tahun 2015-2019, dapat diartikan bahwa struktur kepemilikan tidak dapat menjelaskan adanya pengaruh terhadap CSR. Kepemilikan institusional dan kepemilkan asing berpengaruh negatif terhadap nilai perusahaan, dapat diartikan bahwa semakin tinggi kepemilikan institusional dan kepemilikan asing justru akan menurunkan nilai perusahaan pada perusahaan tekstil dan garment yang terdaftar di Bursa Efek Indonesia pada tahun 2015-2019. Kepemilikan manajerian dan CSR tidak berpengaruh terhadap nilai perusahaan pada perusahaan tekstil dan garment yang terdaftar di Bursa efek Indonesia (BEI) tahun 2015-2019, , hal ini mengindikasikan bahwa kepemilikan manjerial dan CSR tidak dapat menjelaskan adanya pengaruh terhadap nilai perusahaan. CSR tidak dapat memediasi antara hubungan kepemilikan institusional, kepemilikan manajerial dan kepemilikan asing dengan nilai perusahaan pada perusahaan tektil dan garment yang terdaftar di Bursa Efek Indonesia tahun 2015-2019.

\section{Saran}

Peneliti selanjutnya diharapkan dapat mempertimbangkan untuk menggunakan metode penelitian kualitatif maupun campuran, agar hasil penelitian dapat menggambarkan keadaan perusahaan yang sesungguhnya. Peneliti selanjutnya tidak hanya befokus pada sektor utama yang dipilih menjadi sampel, melainkan mencoba menerapkan pada perusahaan yang bergerak pada sektor lain. Peneliti selanjutnya untuk mempertimbangkan dalam menggunakan alat analisis lainnya yang lebih variatif untuk menguji mediasi. Penelitian ini masih memiliki keterbatasan yaitu, penelitian ini menggunakan data sekunder dengan metode penelitian kuantitatif, dan kemungkinan akan menghasilkan hasil analisis yang berbeda dengan penelitian yang menggunakan metode kuantitatif maupun campuran. Sampel yang digunakan juga hanya pada industri tekstil dan garment sehingga hasil penelitian tidak dapat digeneralisasi pada sektor lain. Pada variabel nilai perusahaan hanya menggunakan pendekatan Price 
to Book Value (PBV), kemungkinan ukuran ini belum bisa menggambarkan secara ukuran nilai perusahaan dan peneliti selanjutnya dapat menggunakan ukuran lain seperti Price Earning Ratio (PER) dan Tobin's Q. Kemudian hasil uji koefisien determinasi pada nilai perusahaan masih relative kecil yaitu sebesar $25,5 \%$. Hal ini menunjukkan masih terdapat variabel lain yang dapat mempengaruhi nilai perusahaan yang berada diluar penelitian ini.

\section{REFRENSI}

Anggraini, F.D dan Herlina, E. (2018), The Effect of Corporate Social Responsibility and Ownership Structure on Firm Value in Food and Beverage Companies in South East Asia. The Indonesian Accounting Review, Vol. 8, No. 2: 219-228.

Astuti et al, (2018). Analysis Effect on Firm Size, Institusional Ownership, Profitability, And Leverage on Firm Value with CSR Disclosure as mediatings Variables. Jurnal Bisnis Strategi, Vol.2, No.2: 95-109.

Baron dan Kenny, (1986). The Moderators-Mediator Variable Distinction in Social Psychological Research, Journal of Penality and Social Psychology, Vol. 51, No. $6: 1173-1182$.

Dewi, Kadek Ria Citra dan I Gede Sanica. 2017. "Pengaruh Kepemilikan Institusional, Kepemilikan manajemen, dan Pengungkapan Corporate Social Responsibilityterhadap Nilai Perusahaan Pada Perusahaan Manufaktur yang Terdaftar di Bursa Efek Indonesia” ISSN: 2528- 1216. Economics 3. Hal 305-360

Edison, A. (2017). Struktur Kepemilikan Asing, Kepemilikan Institusional dan Kepemilikan manajerial Pengaruhnya terhadap Luas Pengungkapan Corporate Social Responsibility (CSR) (Pada Perusahaan Sektor Utama yang terdaftar di Bursa Efek Indonesia Tahun 2013-2014). Jurnal Bisnis dan manajemen, 11 (2), 164-175.

Eriandani. (2013). Pengaruh Institusional Ownership, dan Managerial Ownership Terhadap Pengungkapan CSR. Simposium Nasional Akuntansi XVI Manado.

Hartana, I. B. P. R., \& Putra, N. W. A. (2017). Pengaruh Kepemilikan manajerial dan Kepemilikan Institusional Pada Nilai Perusahaan Dengan Corporate Social Responsibility Sebagai Pemoderasi. E-Jurnal Akuntansi Universitas Udayana, 21(3), 1903-1932.

Herlina \& Diputra. (2018). Implementasi Rumus Sobel pada Web dengan Topik Regresi Linier Menggunakan Variabel mediating. Jurnal Algoritma, Logika dan Komputasi. Vol.1, No.1.

(https://regional.kompas.com/read/2018/01/23/11291801/cemari-sungaipabrik-tekstil-indobaratdihukum-denda-rp-2-miliar).

(https://tirto.id/limbunglimbah-bau-pt-rum-pabrik-serat-rayon-seragam-tni-c8KF).

(https://www.topbusiness.id/16791/inilah-daftarpemenang-top-csr-2018.html).

(https://industri.kontan.co.id/news/panbrothers-pbrx-bukukan-kenaikan-laba-107-2018-menjadi-us162-juta)

Karima, Naila. 2014. Pengaruh Kepemilikan manajemen, Kepemilikan Institusional, Dan Kepemilikan Asing Terhadap Pengungkapan Tanggung Jawab Sosial Perusahaan. Surakarta: Universitas Sebelas Maret.

Kim.W.S., et al (2018). Corporate Social Responsibility, Ownership Structure, and Firm Value : Evidence from Korea, Sustainability MDPI, 10. 2947.

Linda.S.W \& Nyoman. A. (2019). Pengaruh Profitabilitas, Likuiditas, Kepemilikan Institusional, dan Kepemilikan manajerial Terhadap Nilai Perusahaan. E-Jurnal manajemen, Vol.8, No.10.

Negara, I., K. (2019). Analisis Pengaruh Good Corporate Governance Terhadap Nilai Perusahaan dengan CSR sebagai Variabel Pemoderasi. Jurnal Magister manajerial UNRAM, Vol. 8, (No.1) : 46.

Pradana, F. A.,\& Suzan, L. (2016). Pengaruh Struktur Kepemilikan, Ukuran Perusahaan dan Umur Perusahaan terhadap Pengungkapan Corporate Social Responsibility Studi Empiris pada Perusahaan Manufaktur yang Terdaftar dalam Bursa Efek Indonesia. E-Proceeding of Management, 3(1), 339-347. 
Purbopangestu \& Subowo, (2014). Pengaruh Good Corporate Governance Terhadap Nilai Perusahaan dengan CSR Sebagai Variabel mediating. Accounting Analysis Journal, Vol.3 ,No. 3.

Purwanto dan Sulistyastuti, (2017). Metode Penelitian Kuantitatif. Yogyakarta : Gava Media.

Rachman, Nurdizal M, dkk. (2011). Panduan Lengkap Perencanaan CSR (Corporate Social Responsibility). Jakarta: Penebar Swadaya.

Rahmah. Dita. (2015). Faktor-Faktor Yang Mempengaruhi Pengungkapan CSR. Jurnal Bisnis dan manajemen. Vol 5, No.2.

Rely, G. \& Arsjah. R.J. (2018). An Effecting of Foreign Ownership Structure in Firm Value Towards Offshore Debt Financing in Manufacturing Firms. Research Journal of Finance and Accounting, Vol.9, No.12.

Santi et al (2017). Influence of Managerial Ownership and Foreign Ownership ON Firm Value Study in Companies.

Siregar \& Pambudi (2017). Pengaruh Kepemilikan manajemen, Kepemilikan Institusional dan Return On Equity Terhadap Nilai Perusahaan Pada Perusahaan Manufaktur.

Sissandhy dan Sudarno, (2014). Pengaruh Kepemilikan Asing Terhadap Nilai Perusahaan dengan Pengungkapan CSR Sebagai Variabel mediating, Diponegoro Journal of Accounting, Vol.3, No.2 :1-7.

Spence, Michael. (1973). Job Market Signaling. The Quarterly Journal of Economics, 3(87) 355-374.

Sukirni Dwi (2012). Kepemilikan manajemen, Kepemilikan Institusional, Kebijakan Dividen dan Kebijakan Hutang Analisis Terhadap Nilai Perusahaan. Accounting Analysis Journal. 1 (2).

Undang-undang Nomor 40 Tahun 2007, Pasal 74 Tentang Perseroan Terbatas

Wardani, Chandrarin, Rahman. (2017) Pengaruh Kepemilikan Institusional Terhadap Nilai Perusahaan Dengan Keputusan Investasi, Keputusan Pendanaan Dan Kebijakan Dividen Sebagai Variabel Moderasi. jurnal ilmiah ilmu akuntansi dan pajak. Vol 1 No 2.

Widianingsih dewi. (2018) "Kepemilikan manajemen, Kepemilikan Institusional, Komisaris Independen, serta Komite Audit pada Nilai Perusahaan dengan Pengungkapan CSR sebagai Variabel Moderating dan Firm Size sebagai Variabel Kontrol". Jurnal akuntansi dan pajak. Vol. 19 No 1, 38-52 STEKOM Indonesia

Widiastuti,Utami, Handoko (2018). "Pengaruh Ukuran Perusahaan, Tipe Industri, Growth, Dan Media Exposure Terhadap Pengungkapan Tanggung Jawab Sosial Perusahaan". Riset Akuntansi dan Keuangan Indonesia, 3(2), 2018.

Zulvina, et al (2017). Pengaruh Struktur Kepemilikan Terhadap Nilai Perusahaan dengan Pengungkapan CSR sebagai Variabel Intervening. JOM Fekon. Vol. 4, No.1. 